\title{
UV mutagenesis treatment for improved production of endoglucanase and $\beta$-glucosidase from newly isolated thermotolerant actinomycetes, Streptomyces griseoaurantiacus
}

Adepu K. Kumar

\begin{abstract}
Background: Bioconversion of cellulosic biomass into fuel ethanol involves several steps, among which enzymatic breakdown of cellulose into fermentable sugars play a significant role. The key enzymes involved in cellulosic breakdown are mainly endoglucanases and $\beta$-glucosidases. Even though the biochemical and molecular characterization of number of endoglucanases and $\beta$-glucosidases was extensively studied, still there is a demand for novel microbial cellulases for industrial applications. Among the group of actinomycetes, Streptomyces spp. are well known as a cellulase producer. The advantage of using actinomycetes is being that production process could be easily scaled-up to commercial levels. However, recent research studies have shown that the production of cellulases from actinomycetes could also be significantly improved by employing different types of strain improvement methods, thus achieving high yields of extracellular proteins. Besides this, highly thermostable and broad $\mathrm{pH}$ range cellulases are required for bioethanol application.

Results: A lignocellulose degrading actinomycetes strain was newly isolated and identified as Streptomyces griseoaurantiacus. Strain improvement using UV mutagenesis developed two mutants (SGuv30 and SGuv5) with 57.4 $\%$ and $12.8 \%$ higher endoglucanase and $\beta$-glucosidase activities. The cellulases (endoglucanases and $\beta$ glucosidases) were found to be highly thermostable with no loss in enzyme activities at $80^{\circ} \mathrm{C}$ for 60 min and nearly $80 \%$ of initial activity was retained at $90^{\circ} \mathrm{C}$. Enzyme assays in presence of additives showed that $\mathrm{CoCl}_{2}$, $\mathrm{CaCl}_{2}$, and $\mathrm{FeSO} 4$ increased $\beta$-glucosidase activity but showed negative effect on endoglucanase activity. However, both the enzyme activities were significantly enhanced by addition of PEG 8000, sodium azide and $\mathrm{MnSO}_{4}$.

Conclusions: Strain improvement of S. griseoaurantiacus was performed by UV mutagenesis where two mutant strains (SGuv30 and $S_{U V v 5}$ ) were developed with improved endoglucanase and $\beta$-glucosidase activities. Cellulase production in submerged fermentation was carried out using a cheap lignocellulosic biomass residue, rice straw as a sole source carbon. The results clearly show that the mutant strains produced high-efficient cellulases that are stable at a broad pH range at very high temperatures. Besides, the mutants also showed high extracellular protein secretions, which could be promising in reducing the overall cellulase production costs at large scale.
\end{abstract}

Keywords: Cellulase; Endoglucanase; $\beta$-glucosidase; Actinomycetes; Lignocellulosic biomass

Correspondence: kiranbio@gmail.com

Bioconversion Technology Division, Sardar Patel Renewable Energy Research Institute, Near BVM Engineering College, Post Box No. 2, Vallabh Vidyanagar 388120, Gujarat, India 


\section{Background}

Lignocellulosic biomass is available in plenty and is an inexpensive renewable bioresource for bioconversion to biofuels. However, this conversion is quite difficult owing to the complexity of the plant cell wall materials that are innately designed to resist microbial degradation. Among these, celluloses are one of the major structural components which could be converted into fuel ethanol with the help of microbial cellulose degrading enzymes, namely cellulases. This group of enzymes catalyze the hydrolysis of cellulose and other cellooligosaccharides into fermentable sugars. Primarily, but not limited to, the cellulase system consists of three major enzymes, viz. exoglucanase (avicelase), endoglucanase (CMCase) and $\beta$-glucosidase (cellobiase). In nature, a number of bacteria and fungi produce cellulases to hydrolyze the insoluble polysaccharides to soluble oligomers and subsequently to monomeric sugars [1]. The production and application potential of diverse microbial cellulases is largely explored using a variety of growth substrates, and voluminous research reports and review articles are published in this area [2-5]. Actinomycetes, especially Streptomyces spp, are known to produce cellulose-degrading enzymes and have attracted considerable interest among the researchers due to their potential applications in the recovery of fermentable sugars from the hydrolysis mixture. Streptomyces spp. are also capable of producing an array of different extracellular enzymes including cellulases, xylanases, and chitinases [6]. Synergistic action of these enzymes is vital for complete enzymatic hydrolysis of cellulose [7]. During the recent past the intense basic and applied research studies revealed the commercial significance and industrial applicability of novel potential cellulases to a greater extent [8-10]. The production economics of cellulosic ethanol from lignocellulosic residues is largely dependent on the enzyme cost especially in the bioconversion processes [11]. However, continuous efforts towards cost reduction have been directed for increasing the enzyme production levels, identification of hyperactive cellulose-degrading microbial strains, efficient ethanol fermentation techniques and enzyme recovery systems, etc. [12]. Besides these, use of different mutagenic agents for microbial strain improvement and fermentation processes was demonstrated [13], where simultaneous treatments with $N$-methyl- $N^{\prime}$-nitro$N$-nitrosoguanidine (NTG), ethidium bromide, and UV either alone or in combination were employed for higher endoglucanases [14].

The present investigation is on isolation of cellulaseproducing actinomycete strains from agricultural and plant waste residues such as decaying woods and aged tree trunk burrows and to screen the microbe for robust utilization of different locally available lignocellulosic biomass residues. We also report on increasing cellulase production levels by applying traditional UV mutagenesis treatment and biochemical characterization of the crude cellulase enzymes (endoglucanase and $\beta$-glucosidase) from two mutant strains.

\section{Methods}

\section{Substrate, chemicals, and media}

Rice straw was obtained from local agricultural fields and was used as carbon substrate for cellulase production. Sodium dodecyl sulphate-polyacrylamide gel electrophoresis (SDS-PAGE) molecular weight markers were purchased from Bio-Rad Laboratories, Hercules, CA. Bovine serum albumin (BSA), $p$-nitrophenyl- $\beta$-D-glucopyranoside (PNPG), carboxymethyl cellulose (CMC), cellobiose, and 4-methylumbelliferyl- $\beta$-D-glucopyranoside (MUG) were purchased from Sigma (St. Louis, MO, USA). All other reagents were obtained from commercial sources and were of analytical grade.

\section{Microbial isolation and screening}

Cellulase producing microbes were isolated from diverse environmental places such as soil and water samples, decaying carton box scrapings, degrading wood pieces, and salt pans near the coastal marine areas of state of Andhra Pradesh, India. The samples (1 g each) were crushed with mortar and pestle and were then suspended in $10 \mathrm{ml}$ of sterile distilled water. A $10^{3}$ dilution of the samples was made and spread plated on IGA medium agar plates comprising $0.5 \%$ peptone, $0.5 \%$ yeast extract, $0.5 \%$ malt extract, $0.5 \%$ glycerol, $3 \% 10 \times$ mineral salt medium, and $1.5 \%$ agar. The composition of mineral salt medium is given in Additional file 1: Table S2. All plates were then incubated at $40{ }^{\circ} \mathrm{C}$ for at least 2-3 weeks. Further, the microbes are sub-cultured onto fresh agar plates in order to ensure the purity of the selected colonies. All the cultures were periodically maintained on sterile actinomycete isolation agar plates (HiMedia Laboratories, Mumbai, India) and stored at $4{ }^{\circ} \mathrm{C}$ for further use.

Cellulose-degrading microbes were screened using actinomycete isolation agar plates containing $0.5 \% \mathrm{CMC}$ and $10 \mathrm{mM}$ MUG, separately. The plates were then incubated for $48 \mathrm{~h}$ at $40{ }^{\circ} \mathrm{C}$. For endoglucanase production, the plates were stained with $0.05 \%$ congo red dye, and for $\beta$-glucosidase production, the plates were directly viewed under UV light. A potential cellulase-producing microbe for the current investigation was selected based on the maximum cellulolytic index and intensity of fluorescence. The cellulolytic index value of the actinomycetes was calculated using the microbial colony size and the size of zone of clearance.

\section{Molecular identification}

Among the potential cellulase-producing microorganisms, an actinomycete strain denoted by SG14 was 
selected in the present study. The genomic DNA was isolated using genomic DNA isolation kit (Bangalore Genei, India). Consensus primers (forward primer: $5^{\prime} \mathrm{C}$ GCGGCCTATCAGCTTGTTG'3 and reverse primer: 5' CCGTACTCCCCAGGCGGGG'3) were used for PCR amplification of $16 \mathrm{~S}$ rRNA. The PCR product was then purified and subjected to DNA sequencing. The 16 SrRNA was submitted to NCBI database with GenBank ID KR094972. The nucleotide sequence was analyzed using Blastn, and multiple sequence analysis was performed using clustalX software using the top 20 consensus sequences obtained from the NCBI databank ( $>98 \%$ sequence identity). A phylogenetic tree was prepared using neighbor-joining method with 1000 bootstrap replicates. Mega 5.0 software was used for tree analysis [15].

\section{Media optimization and growth on different lignocellulosic residues}

For cellulase production in submerged fermentation, seed inoculum was prepared in actinomycete broth medium (HiMedia Laboratories, Mumbai, India). Preliminary cellulase productions were tested using $1 \%(w / v)$ $\mathrm{CMC}$ as carbon source in different growth media compositions viz. minimal salt media, Mandels mineral media [16], Czapek media [17], and Vogel's mineral media [18]. The detailed composition of growth media were given in Additional file 1: Tables S2 to S5. Production of cellulase was tested on different ligocellulosic biomass residues. The carbon sources tested were rice straw (RS), wheat bran (WB), rice husk $(\mathrm{RH})$, wheat husk (WH), coco pith (CP), saw dust (SD), Walseth cellulose (WC), cardboard waste $(\mathrm{CW})$, and newspaper waste $(\mathrm{NW})$, respectively. Except WC, other carbon sources were desized to $0.5-1 \mathrm{~cm}$ using a hammer mill machine and subjected to extensive washing with distilled water and finally dried at $60{ }^{\circ} \mathrm{C}$ overnight until the moisture content was $<5 \%$, while the WC substrate was prepared using commercial cellulose powder (Sigma Aldrich, USA) and pre-treated with $83 \%(w / v)$ phosphoric acid for $25 \mathrm{~h}$ at $40{ }^{\circ} \mathrm{C}$. The precipitate obtained from the Buchner funnel filtration method was then collected and washed twice with $70 \%$ $(v / v)$ ethanol and neutralized to $\mathrm{pH}$ 7.0. Finally, the precipitate was dehydrated by acetone rinsing and dried under vacuum. For submerged fermentation, $100 \mathrm{ml}$ of minimal media was placed in a 500-ml Erlenmeyer flask supplemented with $1 \%(w / v)$ rice straw. The growth media were inoculated with $4 \%$ spore suspension and incubated at $40{ }^{\circ} \mathrm{C}$ at $160 \mathrm{rpm}$ for 5 days. The culture broth was filtered through Whatman filter paper $(9 \mu \mathrm{m}$ size), and the filtrate was then centrifuged at 10,000 rpm for $30 \mathrm{~min}$. The clear supernatant was collected and treated as the crude cellulase enzyme for biochemical analysis.

\section{Determination of cellulase activities}

Endoglucanase activity was assayed by incubating $0.5 \mathrm{ml}$ of crude enzyme with $0.5 \mathrm{ml}$ of $2 \% \mathrm{CMC}$ in citrate buffer $(50 \mathrm{mM}, \mathrm{pH} 5.0)$ for $30 \mathrm{~min}$ at $60{ }^{\circ} \mathrm{C}$. The reducing sugars generated were determined by standard dinitrosalicylic acid (DNSA) method [19]. $\beta$-Glucosidase assay was carried out by mixing $0.2 \mathrm{ml}$ of culture supernatant with $0.2 \mathrm{ml}$ of $0.01 \mathrm{M}$ PNPG and $1.6 \mathrm{ml}$ of citrate buffer $(50 \mathrm{mM}, \mathrm{pH}$ 5.0). The reaction mixture was then incubated for $30 \mathrm{~min}$ at $60{ }^{\circ} \mathrm{C}$. Reaction was stopped by the addition of $4 \mathrm{ml} \mathrm{NaOH}$-glycine buffer $(0.2 \mathrm{M}, \mathrm{pH}$ 10.6) and measured by colorimetric method [20]. The amount of enzyme required for liberating either $1 \mu \mathrm{g}$ of glucose or $1 \mu \mathrm{g} p$-nitrophenol per minute under the standard assay conditions was considered as one unit of endoglucanase or $\beta$-glucosidase activity unit, respectively. All the assay experiments were carried out in triplicates and mean values are given.

\section{Zymogram analysis using non-denaturing SDS-PAGE}

Non-denaturing SDS-PAGE was performed for identification of endoglucanase and $\beta$-glucosidase proteins. Endoglucanase protein bands were detected using the congo red dye staining method of an overlaying gel containing $2 \% \mathrm{CMC}$, while $\beta$-glucosidase active protein bands were detected in the gel by incubating with $10 \mathrm{mM}$ MUG for $30 \mathrm{~min}$ at $45^{\circ} \mathrm{C}$, and then the gel was viewed directly under UV light. Briefly, a $10 \%$ separating gel was prepared, and $30 \mu \mathrm{g}$ of crude cellulase enzyme protein from native and UV-mutated samples was loaded. After electrophoresis, the gel was equilibrated with sodium citrate buffer (50 mM, pH 5.0) for $30 \mathrm{~min}$ and was overlayered on a CMC-containing polyacrylamide gel. This cassette was then enclosed in a plastic wrap and incubated at $60{ }^{\circ} \mathrm{C}$ for $2 \mathrm{~h}$. Post incubation, the CMC-containing gel was peeled off and was stained with $0.2 \%$ congo red solution for $1 \mathrm{~h}$. To visualize the zone of clearance corresponding to the endoglucanase activity, destaining was performed with $1 \mathrm{M} \mathrm{NaCl}$. The developed gels were visualized and digitally imaged. Protein concentration was determined using BSA as standard following the method described by Bradford [21].

\section{Effect of UV treatment on cellulase production}

Spore suspension from an overnight grown culture was prepared by serial dilution method. A $0.5-\mathrm{ml}$ culture sample with a $10^{6}$ dilution (approximately $10^{5}-10^{6}$ spores $\mathrm{ml}^{-1}$ ) was spread plated onto a $0.5 \% \mathrm{CMC}$ agar plate under sterile conditions. Each petri plate was then exposed to a UV tube $(6 \mathrm{~W}, 240 \mathrm{~nm})$ with a constant $10-\mathrm{cm}$ distance for a treatment period of $15 \mathrm{~s}$ to $60 \mathrm{~min}$. The UVtreated petri plates were taken out at regular intervals $(15$, 30 , and $45 ; 1,5,15,30$, and $60 \mathrm{~min}$ ) and incubated at $40{ }^{\circ} \mathrm{C}$ for $48 \mathrm{~h}$. The survivor microbial colonies after the UV 
treatment were then selected for cellulase production by a similar zone of clearance method either using $0.05 \%$ congo red dye as mentioned earlier. The selected colonies were further screened by analyzing the endoglucanase and $\beta$-glucosidase activities using rice straw as sole source of carbon in submerged fermentation.

\section{Determination of optimum $\mathrm{pH}$, temperature, and stability} The enzyme reactions were carried out separately in buffer solutions at varying $\mathrm{pH}(\mathrm{pH}$ 2.0, $\mathrm{pH}$ 5.0, $\mathrm{pH}$ 7.0, $\mathrm{pH}$ 9.0, and $\mathrm{pH} 11.0$ ) and temperature $\left(40\right.$ to $100{ }^{\circ} \mathrm{C}$ with $10{ }^{\circ} \mathrm{C}$ increments). The endoglucanase and $\beta$-glucosidase activities were measured using the assay methods as mentioned in the above section. For $\mathrm{pH}$ stability studies, the enzyme samples were incubated in different test buffer solutions with varying $\mathrm{pH}(\mathrm{pH} 2.0, \mathrm{pH} 5.0, \mathrm{pH} 7.0, \mathrm{pH} 9.0$, and $\mathrm{pH}$ 11.0) for 30 to $60 \mathrm{~min}$ at $60{ }^{\circ} \mathrm{C}$, and then the residual enzyme activities were measured in sodium citrate buffer (50 mM, pH 5.0). For temperature stability studies, the enzyme samples were incubated at different test temperatures $\left(60,80,90\right.$, and $\left.100{ }^{\circ} \mathrm{C}\right)$ in sodium citrate buffer (50 mM, pH 5.0) for different time periods, and residual activities were measured.

\section{Effect of metal ions and chemical reagents}

The enzyme samples were mixed with different metal ions, chemical reagents, and solvents, and then the effect of these additives on the enzyme activity was analyzed. The test compounds used were (10 mM each) $\mathrm{MgSO}_{4}$,
$\mathrm{MgCl}_{2}, \mathrm{CoCl}_{2}, \mathrm{CaCl}_{2}, \mathrm{CuSO}_{4}, \mathrm{MnSO}_{4}, \mathrm{FeSO}_{4}, 0.02$ \% sodium azide, 0.8 \% Tween 20, and 20 \% PEG 8000. Control experiments were also analyzed voiding either the chemical agent or the enzyme to nullify the background absorbance on the activity measurements.

\section{Results and discussion Microbial identification}

The present investigation is on a cellulase-producing actinomycete strain, Streptomyces griseoaurantiacus, which could tolerate high UV radiation for a maximum period of $60 \mathrm{~min}$. The extracellular cellulase production and corresponding enzyme activities were found to be increased significantly after UV treatment. A total of 78 cellulaseproducing microbes (bacteria and actinomycetes) were isolated from various natural habitats. Among these isolates, an actinomycete with maximum zone of clearance ratio on the CMC agar plate with a cellulolytic index value of $34 \mathrm{~mm}$ was selected (Additional file 1: Figure S1). Molecular identification and phylogenetic analysis revealed that the microbial strain belongs to Streptomyces spp. with a close relation to $S$. griseoaurantiacus NBRC 15440 (Fig. 1). Use of purified cellulose or its products like CMC as a growth carbon source is uneconomical for large-scale production of cellulases. Hence, different locally available cheap lignocellulosic residues were tested for microbial cellulase production (Fig. 2). Among the test carbon substrates, rice straw-grown culture extracts showed maximum endoglucanase activity $\left(2.84 \pm 0.2 \mathrm{U} \mathrm{ml}^{-1}\right)$.

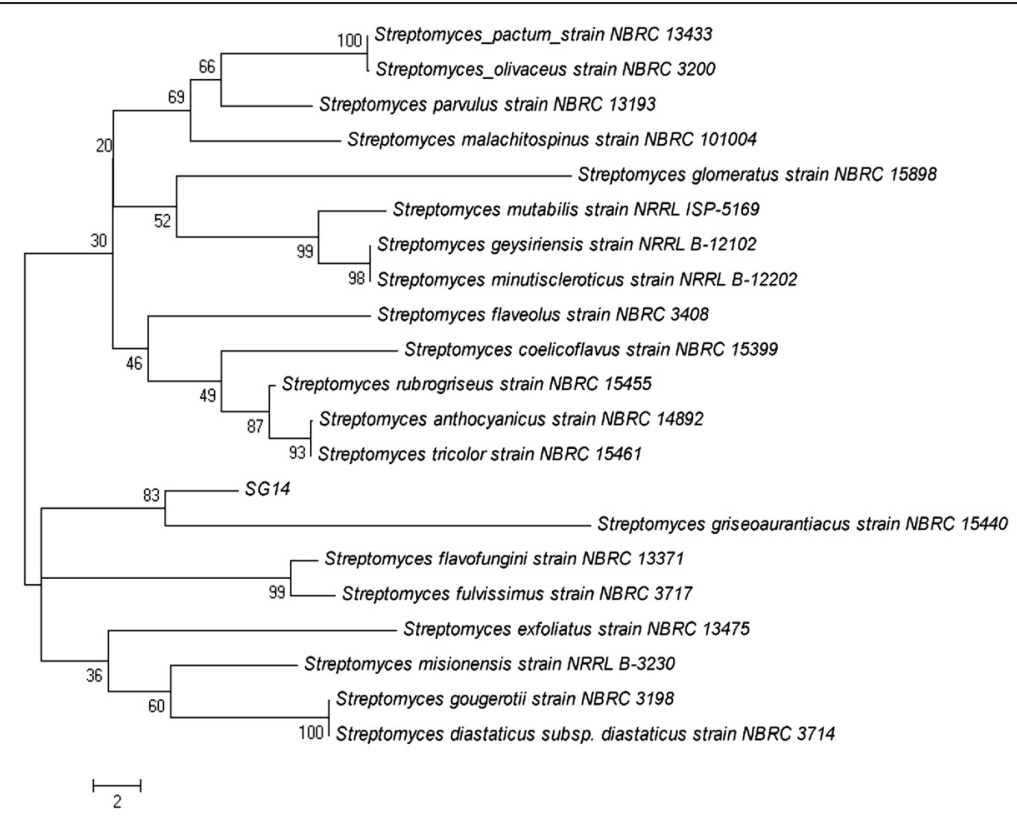

Fig. 1 Identification of cellulose-degrading actinomycetes using 16S rRNA sequence Top 25 sequences homologous to microbial 16S ribosomal partial sequence database were collected from NCBI. The phylogenetic tree was prepared using NJ method with 1000 bootstrap replicates in MEGA 5.2 software [15]. The microbe used in the current study was designated as SG14 


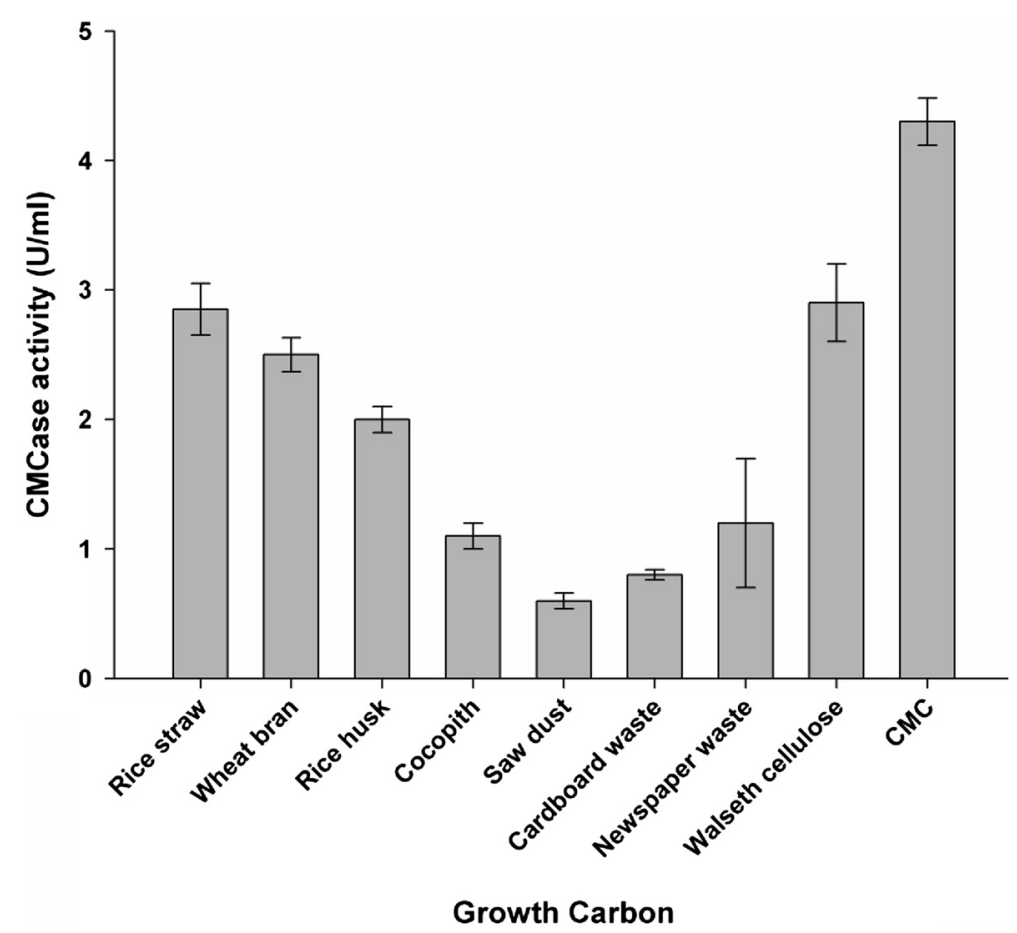

Fig. 2 Production of cellulases in different cellulosic waste materials. The final concentration of the growth substrate used was $1 \%(w / v)$

\section{Microbial growth on rice straw}

Growth optimization studies showed that $1 \%(w / v)$ rice straw and $4 \%(v / v)$ seed inoculum produced maximum endoglucanase (Additional file 1: Figure S2). Thereafter, increase in either rice straw or inoculum concentration had no significant effect on the endoglucanase activity. Similarly, maximum endoglucanase production was observed when grown in minimal growth medium $\left(2.7 \pm 0.2 \mathrm{U} \mathrm{ml}^{-1}\right)$, followed by Vogel's mineral medium $\left(2.2 \pm 0.1 \mathrm{U} \mathrm{ml}^{-1}\right)$ (Table 1). Jaradat et al also reported the influence of growth conditions and medium composition on the cellulase production from Streptomyces sps [22]. In general, the enzyme production depends on the amount of nitrogen supplementation and its accessibility during microbial growth. Unlike other complex growth mediums, minimal media were economical and comparatively simple in their composition (Additional file 1: Table S2). Since no significant difference was observed in cellulase activities, further experiments were performed using rice straw as the sole source of carbon and minimal medium for microbial growth.

\section{UV mutagenesis and zymogam analysis}

Mutational analysis was performed using traditional UV treatment of the actinomycete for increasing cellulase production. Based on the endoglucanase and $\beta$-glucosidase enzyme activities the prominent UV mutant strains were selected for further biochemical studies. However, initial screening of the mutants was established on the index ratio of the zone of clearance. The zone of clearance is indicated by the visible growth of the microbial colony to the degraded CMC agar plate as described in the "Methods" section. The isolated UV mutants were then tested subsequently in submerged fermentation for a minimum of 20 sub-culturing experiments. The variation in the production of endoglucanase and $\beta$-glucosidase and reproducibility of the results were evaluated. Similar results were obtained with all the tested sub-cultured experiments, and no significant alteration in cellulase production was observed. Maximum cellulase production from the mutant cells was obtained within $94 \mathrm{~h}$ as compared to the longer incubation period $(120 \mathrm{~h})$ with the native strain. One of the most intriguing features of $S$. gresioaurantiacus is its high resistance to the UV radiation for a maximum treatment period of $60 \mathrm{~min}$. After $48 \mathrm{~h}$ growth incubation, $>40 \%$ of microbial

Table 1 Cellulase production in different growth media

\begin{tabular}{lll}
\hline Growth media $^{a}$ & \multicolumn{2}{l}{ Enzyme activity $\left(\mathrm{U} \mathrm{ml}^{-1}\right)$} \\
\cline { 2 - 3 } & CMCase & $\beta$-glucosidase \\
\hline Minimal media & $2.7 \pm 0.2$ & $13.4 \pm 0.5$ \\
Mandels mineral media & $1.8 \pm 0.4$ & $6.0 \pm 0.8$ \\
Czapek media & $1.9 \pm 0.2$ & $10.5 \pm 0.3$ \\
Vogel's mineral media & $2.2 \pm 0.1$ & $11.2 \pm 0.6$ \\
\hline
\end{tabular}

${ }^{\mathrm{a} A l l}$ media contain $1 \% \mathrm{CMC}$ as substrate 
cells was found to survive and form colonies after UV treatment. These data clearly indicated that the mutants were not only able to survive harsh conditions but also stable after several generations without any back mutation. Very few microbes in nature could survive such harsh treatments, and to date, no reports are available on such high-UV-tolerant actinomycetes. In most of the microbial mutagenesis studies, UV treatment was generally followed by a chemical treatment to avoid back mutation [14]. However, our studies showed that these mutagens were stable without any drastic changes in the cellulase production profiles and corresponding enzyme activities for several subsequent generations indicating that the developed mutants were highly stable.

Among the tested UV mutants, maximum endoglucanase and $\beta$-glucosidase activities were observed in 30-min and 5-min treated cells (Table 2). Hereafter, the mutant strains for endoglucanase and $\beta$-glucosidase production are referred as $\mathrm{SG}_{\mathrm{UV} 30}$ and $\mathrm{SG}_{\mathrm{UV} 5}$, respectively. The endoglucanase activity in native, $\mathrm{SG}_{\mathrm{UV} 30}$, and $\mathrm{SG}_{\mathrm{UV} 5}$ strains were found to be $2.84 \pm 0.5 \mathrm{U} \mathrm{ml}^{-1}, 4.47 \pm 0.3 \mathrm{U} \mathrm{ml}^{-1}$, and $3.88 \pm 0.4 \mathrm{U} \mathrm{ml}^{-1}$, respectively, whereas the $\beta$-glucosidase activity in native, $\mathrm{SG}_{\mathrm{UV} 30}$, and $\mathrm{SG}_{\mathrm{UV} 5}$ strains were $15.6 \pm$ $0.7 \mathrm{U} \mathrm{ml}^{-1}, 10.4 \pm 0.4 \mathrm{U} \mathrm{ml}^{-1}$, and $17.6 \pm 0.5 \mathrm{U} \mathrm{ml}^{-1}$, respectively (Table 2). From these results, it is clearly evident that the endoglucanase activity in $\mathrm{SG}_{\mathrm{UV} 30}$ and $\beta$-glucosidase activity in $\mathrm{SG}_{\mathrm{UV} 5}$ were nearly 57.4 and $12.8 \%$ higher compared to the native strain. These results were in close agreement with the recent findings from a UV-mutated Aspergillus niger strain, where a twofold increase in endoglucanase activity was reported [23]. Our results suggest that modification of $S$. griseoaurantiacus for cellulase production by UV mutagenesis has a profound effect on overall enzyme production. Similarly, there are few reports on high UV treatment of fungi for enhancing cellulase production. In Trichoderma viride ZY-1, the UV mutant

Table 2 Effect of UV treatment on cellulase activities and protein production

\begin{tabular}{llll}
\hline $\begin{array}{llll}\text { UV treatment } \\
\text { time }(\mathrm{min})\end{array}$ & \multicolumn{2}{l}{ Enzyme activity $\left(\mathrm{U} \mathrm{ml}^{-1}\right)$} & $\begin{array}{c}\text { Protein } \\
(\mathrm{mg} \mathrm{ml}\end{array}$ \\
\cline { 2 - 3 } & CMCase & $\beta$-glucosidase & 0.081 \\
\hline $\begin{array}{llll}\text { Control } \\
0.15\end{array}$ & 2.84 & 15.6 & 0.062 \\
0.30 & 3.20 & 12.0 & 0.074 \\
0.45 & 2.84 & 11.2 & 0.064 \\
1.0 & 2.80 & 4.8 & 0.079 \\
5.0 & 2.32 & 16.0 & 0.096 \\
15.0 & 3.88 & 17.6 & 0.097 \\
30.0 & 3.76 & 12.0 & 0.109 \\
45.0 & 4.40 & 10.4 & 0.115 \\
60.0 & 3.32 & 12.8 & 0.086 \\
\hline
\end{tabular}

produced $98.1 \%$ higher FPase than the native strain [24], while in Aspergillus nidulans, the UV mutant showed 3.96 times more endoglucanase activity than the wild type [25].

The enzyme activity results from the native and UV mutants were also supported by the zymogram analysis data. Non-denaturing SDS-PAGE analysis with equal protein loadings of culture filtrates on a CMC gel from the UVtreated cells showed maximum zone of clearance with the $\mathrm{SG}_{\mathrm{UV} 30}$ strain (Fig. 3). These results further provided evidence for enhanced cellulase production by UV treatment. As shown in Fig. 2, the endoglucanase activity in the native strain and $\mathrm{SG}_{\mathrm{UV} 30}$ strain from the CMC growth substrate was $4.3 \pm 0.2 \mathrm{U} \mathrm{ml}^{-1}$, which was found to be nearly similar $\left(4.47 \pm 0.3 \mathrm{U} \mathrm{ml}^{-1}\right)$ when grown on rice straw. For cost-effective production of enzymes at a commercial scale, use of such cheap lignocellulosic residues is preferred over synthesized carbon substrates.

\section{Effect of $\mathrm{pH}$, temperature and additives on cellulase activity}

Although $\sim 36.6 \%$ higher endoglucanase activity was observed in $\mathrm{SG}_{\mathrm{Uv} 5}$ cells, the $\beta$-glucosidase activity was not found to be increased. This variation in activity levels could be mostly due to the UV-dependent effect on the cellulase-encoding genes, since endoglucanase and $\beta$-glucosidase are two different proteins and are expressed by separate genes. It clearly indicated that UV mutagenesis is a random mutation process. As the mutation occurs at the gene level and mostly involved in thymine dimerization, the translation process of some of the genes might have inhibited by the UV treatment. Further detailed molecular investigation and proteomic studies are required to understand these expressed endoglucanase and $\beta$-glucosidase proteins. Moreover, UV treatment showed significant effect on overall increase in the extracellular protein production.

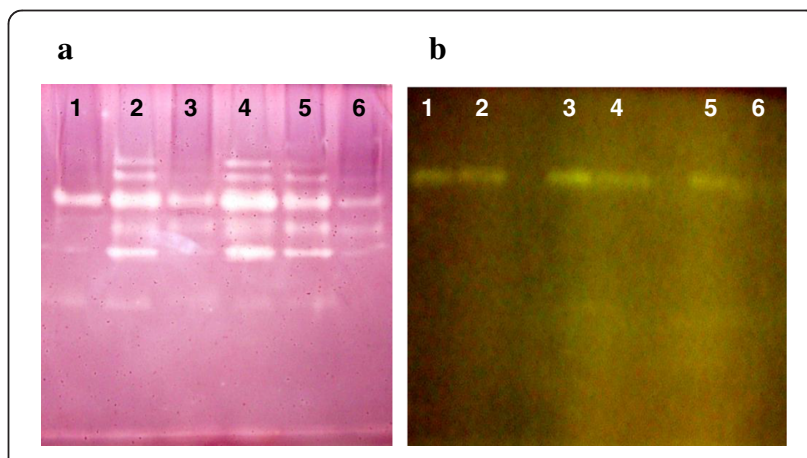

Fig. 3 Zymogram analyses of the culture filtrate after UV treatment. Cells were treated with UV light for different time periods. a CMC gel with congo red dye staining was used for endoglucanase protein detection, and $\mathbf{b}$ MUG gel with UV fluorescence was used for $\beta$-glucosidase protein detection. Lane 1: $0 \mathrm{~min}$, lane 2: $5 \mathrm{~min}$, lane 3: $15 \mathrm{~min}$, lane 4: $30 \mathrm{~min}$, lane 5: $45 \mathrm{~min}$, and lane 6: $60 \mathrm{~min}$, respectively 
The protein concentration in the culture supernatant was increased from 0.081 to $0.115 \mathrm{mg} \mathrm{ml}^{-1}$ after UV treatment (Table 2). Besides this, the reason for low protein production with decreased enzyme activities at higher UV treatment periods may be due to the longer exposures of the microbe to harsh UV radiation which resulted in undesirable genetic modifications inside the cells [26].

The optimum temperature for endoglucanase and $\beta$ glucosidase activity was found to be $60 \pm 5{ }^{\circ} \mathrm{C}$ and $70 \pm$ $3{ }^{\circ} \mathrm{C}$, respectively (Fig. 4a). These results were in close agreement with other published literatures on actinomycetes. Kluepfel [27] reported that Streptomyces lividans grown on xylan showed an optimum endoglucanase activity at $60{ }^{\circ} \mathrm{C}$. However, endoglucanase from Streptomyces T3-1 had an optimum temperature of $50{ }^{\circ} \mathrm{C}$ [28], and Streptomyces reticuli endoglucanase showed an optimum temperature of $55{ }^{\circ} \mathrm{C}$ [29]. At $70{ }^{\circ} \mathrm{C}$, more than $90 \%$ of the endoglucanase was retained, while for $\beta$-glucosidase, a similar residual activity was observed at slightly lower temperatures $\left(50-60^{\circ} \mathrm{C}\right)$. These data clearly indicated that the enzymes work together effectively at their optimum temperature without compromising the activities of the enzyme complex. Cellulases from thermophilic microorganisms are generally reported to be highly thermostable in nature. Our studies also comply with this nature of
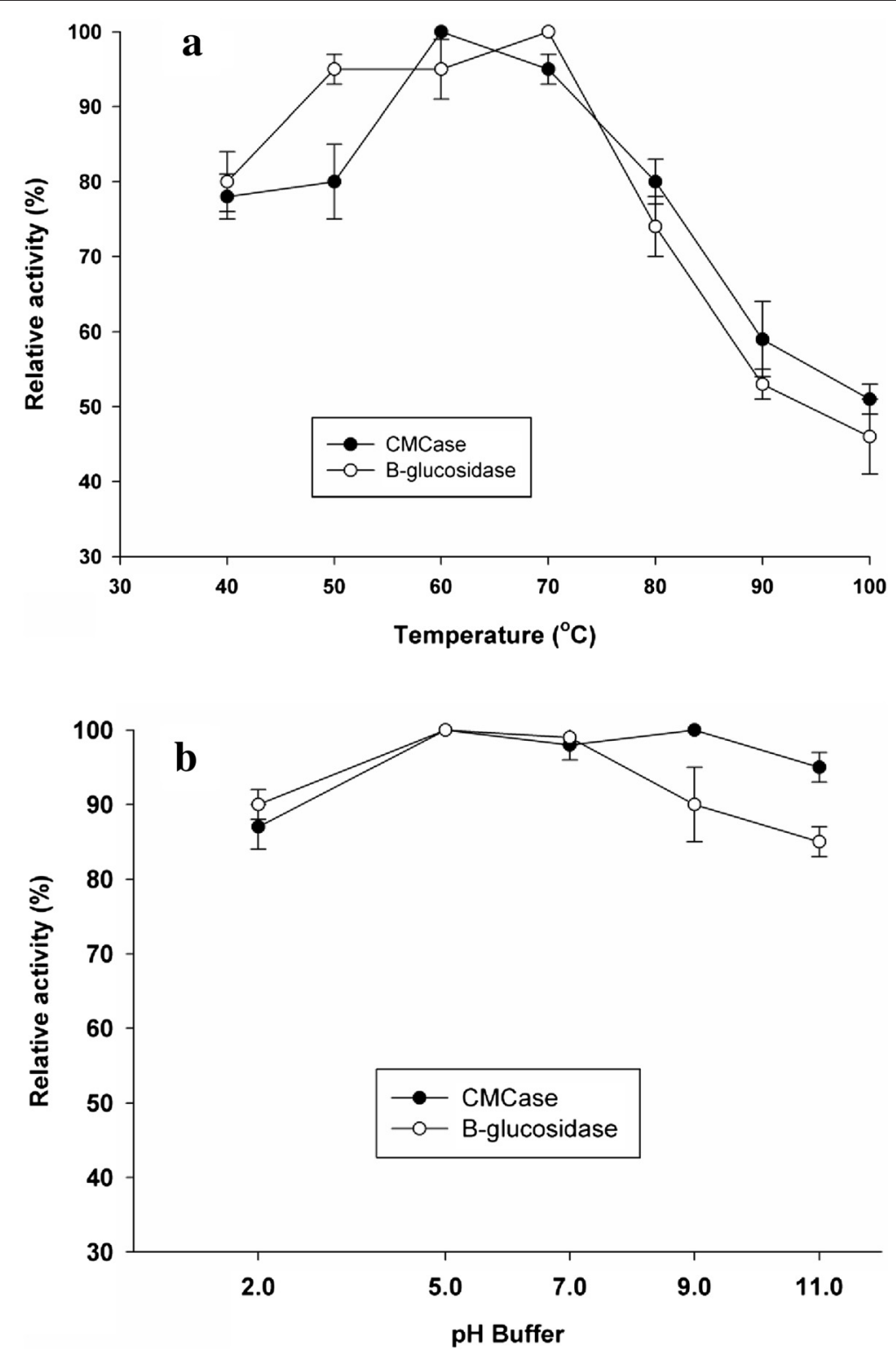

Fig. 4 Effect of temperature (a) and pH (b) on endoglucanase and $\beta$-glucosidase activities 
thermostability. Above $60{ }^{\circ} \mathrm{C}$ incubation, the endoglucanase and $\beta$-glucosidase enzyme activities from the native strain were found to decrease drastically. In comparison to these, the proteins secreted from $\mathrm{SG}_{\mathrm{UV} 30}$ and $\mathrm{SG}_{\mathrm{UV} 5}$ were found to be highly stable and no loss in enzyme activities was observed after incubation at $80{ }^{\circ} \mathrm{C}$ for $60 \mathrm{~min}$, whereas at $90{ }^{\circ} \mathrm{C}, 80 \%$ initial activity was retained for endoglucanase and $\beta$-glucosidase. However, at $100{ }^{\circ} \mathrm{C}$, $50 \%$ endoglucanase and $70 \% \beta$-glucosidase residual activities were observed after 30 and 60 min incubation (Fig. 5a, b). Although both the enzymes were highly thermostable, the data indicated that $\beta$-glucosidase had better stability than endoglucanase.

The stability of the protein in different $\mathrm{pH}$ buffer systems was analyzed, and it was found that $>70 \%$ endoglucanase and $>80 \% \beta$-glucosidase residual activities were retained after 60 min incubation period in $\mathrm{pH} 2.0$ to $\mathrm{pH}$ 11.0 (Fig. 5c, d), except where no significant loss of endoglucanase and $\beta$-glucosidase activity was observed at $\mathrm{pH}$ 5.0 and $\mathrm{pH}$ 7.0, respectively. The data indicated that these proteins were highly stable in broad $\mathrm{pH}$ solutions. In contrary, the endoglucanase and $\beta$-glucosidase proteins from the native strain were not stable either above or below $\mathrm{pH}$ 5.0. The reason behind this drastic improvisation in $\mathrm{pH}$ stability from the mutant strains is not clearly known.

In general, based on the enzyme activity at a specific $\mathrm{pH}$, the cellulase proteins are categorized into three groups, namely acidic, basic, and neutral cellulases. However, it is highly intriguing to ascertain that both the crude endoglucanase and $\beta$-glucosidase have no distinct maximum activity at a specific $\mathrm{pH}$ under the test conditions (Fig. 4b). The enzyme activities were found to be nearly similar in all test buffers with varying $\mathrm{pH}$. The data is strongly evident from the production of multiple endoglucanase and $\beta$-glucosidase enzymes in the crude culture filtrate (Fig. 3a). Although there were multiple $\beta$-glucosidase proteins present in the culture filtrate, only a single prominent $\beta$-glucosidase protein with maximum enzyme activity was clearly visible, while other proteins were not digitally captured due to their low activity (Fig. 3b). However, multiple low molecular weight proteins with $\beta$-glucosidase activity were observed with the naked eye. In nature, microorganisms capable of degrading lignocellulosic materials contain multiple cellulase-producing genes in the genome and
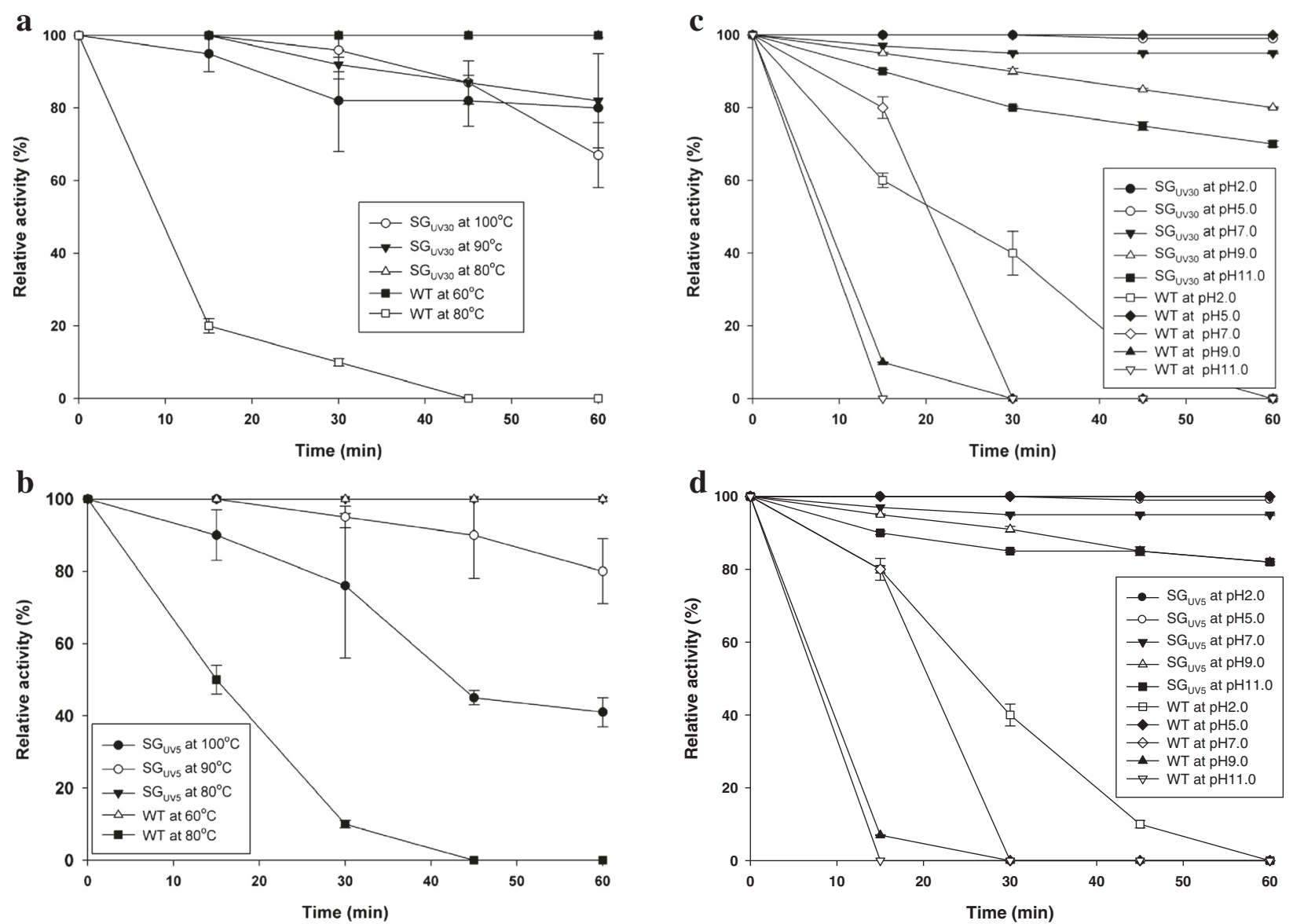

Fig. 5 Thermal and pH stability studies of endoglucanase and $\beta$-glucosidase. Temperature stability analysis of $\mathbf{a}$ endoglucanase and $\mathbf{b} \beta$-glucosidase; pH stability analysis of $\mathbf{c}$ endoglucanase and $\mathbf{d} \beta$-glucosidase 


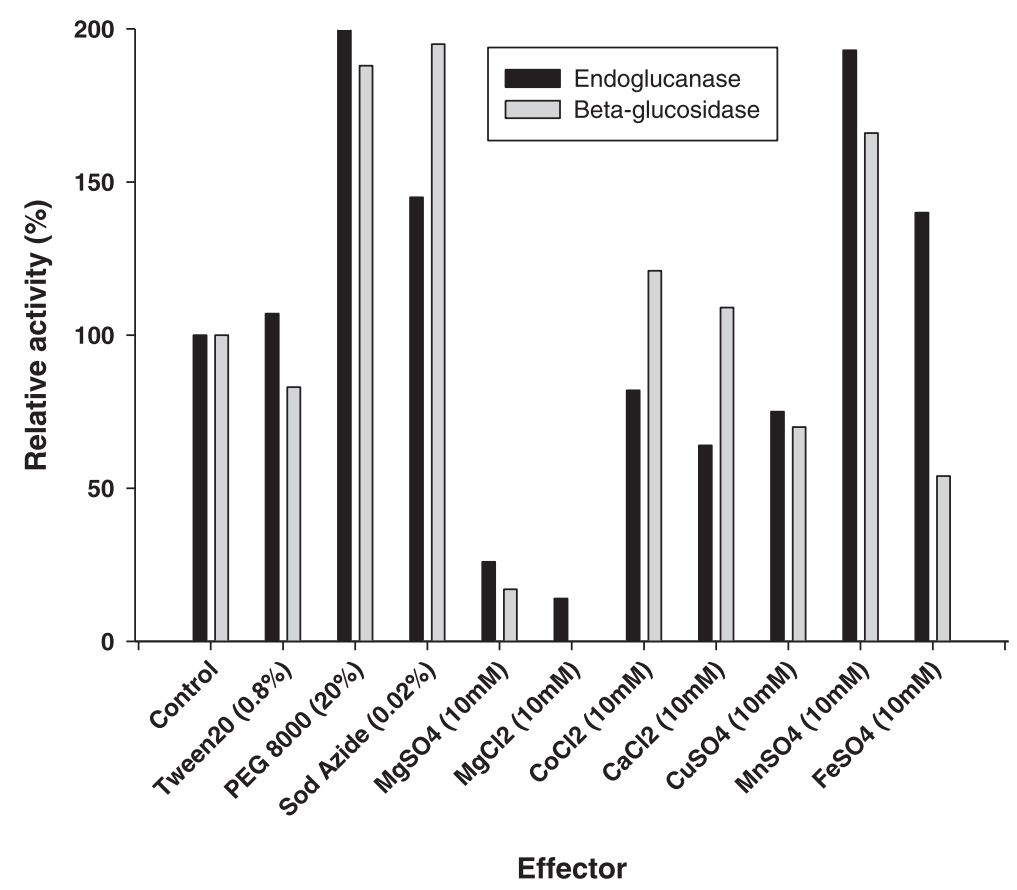

Fig. 6 Effect of metal ions and chemical agents on endoglucanase and $\beta$-glucosidase activities

secrete the proteins into the extracellular environment for efficient synergistic bioconversion of complex lignocellulosic materials into simple substrates for their metabolic growth [30]. Further, the effect of different divalent metals and ionic agents on cellulase activity was also examined. The endoglucanase and $\beta$-glucosidase activities were significantly enhanced in the presence of PEG 8000, sodium azide, and $\mathrm{MnSO}_{4}$. However, $\mathrm{CoCl}_{2}, \mathrm{CaCl}_{2}$, and $\mathrm{FeSO}_{4}$ decreased endoglucanase and increased $\beta$-glucosidase activities (Fig. 6), while $\mathrm{CuSO}_{4}$ alone decreased the enzyme activities. Tween 80 had a marginal effect on the cellulase activities. A strong inhibitory effect was observed for both the enzymes when incubated with $\mathrm{MgSO}_{4}$ and $\mathrm{MgCl}_{2}$, indicating that $\mathrm{Mg}^{+2}$ ions may bind to the critical amino acids near the active site region and inhibit the enzyme catalysis.

Since the cellulases are stable in a broad $\mathrm{pH}$ range, this enzyme cocktail could be used in diverse industrial applications where a specific acidic, basic, or neutral cellulase protein is needed to be supplemented during an individual process step. Moreover, single cellulase enzyme cocktail is preferred over separate cellulase protein with a specific $\mathrm{pH}$ condition, thus reducing the overall cost of the protein. In addition, the crude cellulase protein cocktail also showed broad $\mathrm{pH}$ stability with high potential in cellulosic ethanol production.

\section{Conclusions}

S. griseoaurantiacus was mutated by UV treatment, and two mutant strains $\left(\mathrm{SG}_{\mathrm{UV} 30}\right.$ and $\left.\mathrm{SG}_{\mathrm{UV} 5}\right)$ were developed with improved endoglucanase and $\beta$-glucosidase production and activity. Rice straw was used as a cheap lignocellulosic residue for microbial growth for cellulase production in submerged fermentation. Both the native and mutant strains were able to utilize rice straw very efficiently. The UV mutants showed $57.4 \%$ and $12.8 \%$ higher endoglucanase and $\beta$-glucosidase activities compared to the wild-type enzymes. There was no loss in endoglucanase and $\beta$-glucosidase activities at $80{ }^{\circ} \mathrm{C}$ were found to be highly thermostable with no loss in enzyme activities at $80{ }^{\circ} \mathrm{C}$ for $60 \mathrm{~min}$ and nearly $80 \%$ of initial activity was retained at $90{ }^{\circ} \mathrm{C}$. Studies on purification of the endoglucanases and $\beta$-glucosidases from these mutant strains and their synergistic action on enzymatic saccharification will provide the industrial applicability in cellulosic ethanol production.

\section{Additional file}

Additional file 1: Supporting information. A file showing two supplementary figures and five supplementary tables.

Competing interests

The authors declare that they have no competing interests.

\section{Author's contributions}

AKK designed and performed the research experiments. AKK wrote the paper and approved the final manuscript for publication. 


\section{Author's information}

AKK is a senior scientist at the Bioconversion Technology Division, Sardar Patel Renewable Energy Research Institute, near BVM Engineering College, Vallabh Vidyanagar, Gujarat, India.

\section{Acknowledgements}

The author is thankful to the Director, SPRERI for providing the necessary facilities to carry out this research work. The financial support from the start-up research fund (SPRERI/AKK/RP-2) of SPRERI, Gujarat is highly acknowledged.

Received: 21 February 2015 Accepted: 30 April 2015

Published online: 19 May 2015

\section{References}

1. Rathan RK, Ambili M (2011) Cellulase enzyme production by Streptomyces sp using fruit waste as substrate. Aust J Basic Appl Sci 5:1114-1118

2. Horn SJ, Vaaje-Kolstad G, Westereng B, Eijsink VG (2012) Novel enzymes for the degradation of cellulose. Biotechnol Biofuel 5:45

3. Miettinen-Oinonen A, Londesborough J, Joutsjoki V, Lantto R, Vehmaanpera J (2004) Three cellulases from Melanocarpus albomyces for textile treatment at neutral pH. Enzym Microbial Technol 34:332-341

4. Sukumaran RK, Singhania RR, Pandey AK (2005) Microbial cellulases production, application and challenges. J Sci Indus Res 64:832-844

5. Bhat MK (2000) Cellulases and related enzymes in biotechnology. Biotechnol Adv 18:355-383

6. Manivasagan P, Gnanan S, Sivakumar K, Thangaradjou T, Vijaylaxmi S, Balasubramanian T (2010) Isolation, identification and characterization of multiple enzyme producing actinobacteria from sediment samples of Kodiyakarai coast, the Bay of Bengal. Afr J Microbiol Res 4:1550-1559

7. Berg B, Laskowski R (2006) Litter decomposition: a guide to carbon and nutrient turnover, vol 38, CA, Adv. Ecol. Res. Elsevier Academic Press, San Diego

8. Bajpai P (1999) Applications of enzymes in the pulp and paper industry. Biotechnol Prog 15:147-157

9. Harman GE, Kubicek CP (1998) Trichoderma and Gliocladium: enzymes, biological control and commercial applications, vol 2. Taylor and Francis Ltd, London, pp 393

10. Uhlig H (1998) Industrial enzymes and their applications. In: John Wiley \& Sons, Inc, New York, pp 435

11. Reith $\mathrm{JH}$, den Uil H, van Veen $\mathrm{H}$, de Laat WTAM, Niessen JJ, de Jong E, Elbersen HW, Weusthuis R, van Dijken JP, Raamsdonk L (2002) Coproduction of bio-ethanol, electricity and heat from biomass residues. In: Proceedings of the 12th European conference on biomass for energy, industry and climate protection. 17-21 June 2002, Amsterdam, The Netherlands, 1118-1123.

12. Xu ZH, Bail YL, Xu X, Shi JS, Tao Wl (2005) Production of alkali-tolerant cellulase-free xylanase by Pseudomonas sp. UN024 with wheat bran as the main substrate. World J Microbiol Biotechnol 21:575-581

13. Parekh S, Vinci VA, Strobel RJ (2000) Improvement of microbial strains and fermentation processes. Appl Microbiol Biotechnol 54:287-301

14. Chand P, Aruna A, Maqsood AM, Rao LV (2005) Novel mutation method for increased cellulase production. J Appl Microbiol 98:318-323

15. Tamura K, Peterson D, Peterson N, Stecher G, Nei M, Kumar S (2011) MEGA5: molecular evolutionary genetics analysis using maximum likelihood, evolutionary distance, and maximum parsimony methods. Mol Biol Evol 28:2731-2739

16. Mandels M, Hontz I, Nystrom J (1974) Enzymatic hydrolysis of waste cellulose. Biotechnol Bioeng 16:1471-1493

17. Czapek F (1902) Beitr Chem Physiol Pathol 1:540

18. Vogel HJ (1956) A convenient growth medium for Neurospora (medium N). Microbial Genetics Bulletin 13:42-43

19. Dashtban M, Maki M, Leung KT, Mao C, Qin W (2010) Cellulase activities in biomass conversion: measurement methods and comparison. Crit Rev Biotechnol 30:302-309

20. Kubicek CP (1982) Beta-glucosidase excretion by Trichoderma pseudokoningii: correlation with cell wall bound beta-1,3-glucanase activities. Arch Microbiol 132:349-354

21. Bradford MM (1976) A rapid and sensitive method for the quantitation of microgram quantities of protein utilizing the principle of protein-dye binding. Anal Biochem 72:248-254
22. Jaradat Z, Dawagreh A, Ababneh Q, Saadoun I (2008) Influence of culture conditions on cellulase production by Streptomyces sp. strain J2. Jordan J Biol Sci 1:141-146

23. Irfan M, Javed J, Syed Q (2011) UV mutagenesis of Aspergillus niger for enzyme production in submerged fermentation. Pak J Biochem Mol Biol 44:137-140

24. Yao R, Li M, Deng S, Hu H, Wang H, Li F (2012) Mutagenesis of Trichoderma viride by ultraviolet and plasma. Plasma Sci Tech 14:353-356

25. Lui j, Feng Y, Yu Y, Zhou X, He W (2011) Selection of fungus with high ability of cellulase activity production using UV mutagenesis. International Conference on Consumer Electronics, Communications and Networks (CECNet), 1643-1645

26. Ikehata H, Ono T (2011) The mechanisms of UV mutagenesis. J Radiat Res 52:115-125

27. Kluepfel D, Shareck F, Mondou F, Morosoli R (1986) Characterization of cellulase and xylanase activities of Streptomyces lividans. Appl Microbiol Biotechnol 24:230-234

28. Jang HD, Chen KS (2003) Production and characterization of thermostable cellulases from Streptomyces transformant T3-1. World J Microbiol Biotechnol 19:263-268

29. Schrempf H, Walter S (1995) The cellulolytic system of Streptomyces reticuli. Int J Macromolecules 15:353-355

30. Maki M, Leung KT, Qin W (2009) The prospects of cellulase-producing bacteria for the bioconversion of lignocellulosic biomass. Int J Biol Sci 5:500-516

\section{Submit your manuscript to a SpringerOpen ${ }^{\circ}$ journal and benefit from:}

- Convenient online submission

Rigorous peer review

- Immediate publication on acceptance

- Open access: articles freely available online

- High visibility within the field

- Retaining the copyright to your article

Submit your next manuscript at springeropen.com 